\title{
Divulgação científica e proteção de um patrimônio geológico mundial, o Aquífero Guarani: aplicação inicial no Estado de São Paulo.
}

\author{
Renatta C. C. Lemos Vilela (IC), Celso Dal Ré Carneiro (Orientador)
}

\begin{abstract}
Resumo
A pesquisa faz parte de projeto ambicioso de divulgação, valorização e preservação do Aquífero Guarani no Estado de São Paulo, que envolve docentes, alunos e pesquisadores da Unicamp e de entidades externas. A finalidade é conscientizar a sociedade em geral sobre a necessidade de proteger e usar racionalmente as águas nele contidas. O objetivo principal da pesquisa de Iniciação Científica consiste na produção de paineis educativos concisos sobre o Aquífero, que integrarão Percursos Pedagógicos Geológicos, sendo colocados em áreas de fácil acesso e grande visibilidade. Destacam-se a importância, os atrativos e as medidas de preservação, além de pormenores da história geológica regional.
\end{abstract}

Palavras Chave: Águas subterrâneas, Aquífero Guarani, patrimônio geológico.

\section{Introdução}

As águas subterrâneas exigem extrema atenção da sociedade e dos governos. A extração requer construção de poços, que são obras complexas executadas abaixo da superfície. A legislação é rigorosa para aprovação de novas perfurações, mas os mecanismos de proteção dos aquíferos são pouco exigentes, ou menos bem conhecidos pela sociedade. O Aquífero Guarani ocupa vasto território do Brasil, além de partes da Argentina, Paraguai e Uruguai ${ }^{1}$. Nessa área, todo projeto de (a) aproveitamento de petróleo e gás; (b) uso de pesticidas ("defensivos agrícolas") para produção agrícola-pastoril; (c) atividade industrial; (d) de disposição de resíduos e/ou (e) expansão urbana, deve levar em conta a geologia regional, visando evitar problemas futuros e propiciar adequado planejamento ambiental

O projeto foi desenvolvido com a intenção de conscientizar a população, por meio de paineis, sobre a distribuição, volumes e uso responsável das águas do Aquífero Guarani.

\section{Resultados e Discussão}

Foram desenvolvidos sete paineis de divulgação, apoiados em pesquisa bibliográfica. São paineis complementares porém auto-explicativos, sobre os seguintes temas:

- Aquífero Guarani: um patrimônio geológico mundial. $O$ painel discorre sobre o que é um aquífero, características e imensidão do SAG.

- Aquífero Guarani: como surgiu? O painel relata a formação do aquífero e sua história geológica.

- Aquífero Guarani: usos da água. O painel relata o uso atual das águas no Estado de São Paulo.
- Aquífero Guarani: áreas de recarga. O painel discorre sobre o que são as áreas de recarga.

- Aquífero Guarani: quando, como e por que utilizar? O painel relata como fazer uso mais adequado das águas do aquífero.

- Aquífero Guarani: ameaças. O painel descreve riscos potenciais para as águas, especialmente nas zonas de recarga (áreas de afloramento).

- A Fauna e a flora das formações geológicas que compõem o aquífero. O painel descreve por intermédio de fósseis como era a vida na época de formação do aquífero.

\section{Conclusões}

A divulgação científica sobre águas subterrâneas é essencial para superar uma grande barreira, pois raramente a sociedade tem acesso a dados e conhecimentos nesse campo. Ações que levem a ciência e a tecnologia para perto da vida das pessoas podem ajudá-las a entender melhor 0 ambiente onde vivem. Atividades humanas mal planejadas na área do Aquífero Guarani podem causar contaminações e prejuízos incalculáveis a longo prazo. A qualidade e a integridade das águas precisam ser preservadas a todo custo; portanto, a sociedade e os governos devem ser alertados das ameaças. Os paineis são um bom caminho para se atingir esse objetivo.

\section{Agradecimentos}

A pesquisa foi financiada pelo Programa de Bolsas de Iniciação Científica (PIBIC/CNPq), cujo apoio os autores reconhecem e agradecem.

${ }^{1}$ Gonçales, V.G.; Mantesso Neto, V.; Bartorelli, A.; Carneiro, C.D.R.; Anelli, L.E.; Balsalobre B. 2014. Programa educativo de divulgação, valorização e geoconservação do Aquífero Guarani. In: Congresso Brasileiro de Águas Subterrâneas, 18, Belo Horizonte, 2014. Anais... Belo Horizonte, ABAS. 